\title{
Information Systems for Accreditation Assessment Department base on The Web (Case Study: Informatic Engineering Department)
}

\author{
Mukhamad Nurkamid ${ }^{1}$, Ahmad Jazuli ${ }^{2}$ \\ \{muhammad.nurkamid@umk.ac.id ${ }^{1}$, ahmad.jazuli@umk.ac.id² \\ Department of Informatic Engineering, Universitas Muria Kudus Gondangmanis PO BOX 53 Bae \\ Kudus $^{12}$
}

\begin{abstract}
Accreditation is a process of comprehensive assessment of eligibility of a unit or an educational program on the path to formal education and non formal education and type of every level, the result embodied in the form of a certificate recognition and ranking eligibility issued by an appropriate agency Ministerial Regulation No. 32 Year 2016 of Akreditiasi courses and colleges. During this difficult accreditation assessment identified against which instruments were already good and which is less, so the determination results of accreditation skoring there is still a random value that is spread across several instruments of assessment. This research is designed to help course in preparing the accreditation of study programs making it easy to see the results of assessment, both of which have a high value and low. Applications developed with prototyping development approach. External accreditation applications research is used to help the preparation of accreditation in accordance with the quality standard of BAN PT.
\end{abstract}

Keyword: Forms, accreditation, academic programs, BAN PT.

\section{Introduction}

Accreditation is a form of external quality assurance system is a process used in authorized institutions provide formal recognition that an institution has the ability to perform a particular activity. Accreditation is one form of assessment (evaluation) quality and feasibility of the institution of the College or program of studies conducted by independent organizations or entities outside the College [1]. Data from Ministry of Research, technology and higher education mentions as much as the total of 3,340 4,472 College is not accredited. Such data led to the difference of quality between the campuses of higher education is still very high. Even the Minister of higher education said, "the Total higher education (HE) too much if compared with the total population of Indonesia. Refer to developed countries such as China and Singapore, the number of HE in Indonesia should have no more than 1,000 campuses. China's population reached 1.2 billion people have only about 2,800 campus. Indonesia the total population 250 million peoples, the number of College nearly doubled the height of China[2]. The Ministry of Research, technology and higher education noted this now until January 31, yesterday from 25,862 study programs, there are 23 percent or 5,838 which has not been accredited. Overall, the campus has been accredited 6,521 ' C ', ' B ' accredited 10,623 and 2,880 campus accredited ' A ' [3].

ICCSET 2018, October 25-26, Kudus, Indonesia

Copyright (C) 2018 EAI

DOI 10.4108/eai.24-10-2018.2280611 
Benefits of accreditation in addition to improve the quality of colleges/institutions can also be used as increased competence of graduate students. This means that students who graduated from College have close to a minimum standard of values that have been determined.

The role, of course, has many functions including as organizer of education and teaching, carrying out research for the development of science and technology, carrying out public service and coaching not only academic. In the implementation of real problems faced by the field study program a lot going on. Some of these problems are related to the accreditation assessment is (1) the difficulty of displaying the score-score/rating substandard form, (2) courses have difficulty in identifying the score-score value is of the form quantitative and qualitative, (3) the relevance of the Association documents in each standard are not recorded properly, (4) information document in the form are not updated and consistent so that the required documents have information there are different on each standard and (5) of the course find difficulty in finding locations/layout of the form document is stored. It is aligned with the findings of other related problems manual recording the results of the accreditation process, i.e., the collection, compilation and reporting of data, accreditation is done conventionally takes a long time, supporting documents which were broken and missing that could hinder the process of drafting which will be used as the supporting attachments of the form [4].

The Program study of Informatic Engineering Faculty of Engineering Muria Kudus University last time hosted the accreditation process on 18 March 2016 through SK BAN PT No. 0603/SK/BAN-PT/Akred/S/V/2016.

Web-based information systems (or much of it gives users definitions with information technology) are preferred, because it has many advantages: (1) with information technology can increase communications of the Organization, (2) information technology can support business goals both in the short and long term, (3) information technology can be used for the distribution of complex information, (4) cheap, information technology has helped computerized business processes, and (5) creating new job opportunities, with information technology can create new job opportunities as programmers, system analysts, software developers and hardware, web designer. Web designer part of new job opportunities with the help of information technology [5]. With information systems, organizations can provide information and communication services needed [6]. According to Lyytinen \& Newman (2008) the information system is an organizational system which consists of technical specifications, organizations and elements that need each other which are all reorganized and expanded during the development of information systems[7]. An information system (IS) is an organized collection of people, information, business processes, and information technology, designed to transform inputs into outputs, in order to achieve a goal. Information system use for enhance knowledge work, decision making, problem solving, communicating and coordinating[8]. According to Ralph M Stair in his book entitled "Principle of Information System: A Managerial Approach", it is stated that information systems are a set of interrelated elements that function to collect, manipulate, store and disseminate data and information and are able to provide improvements for a purpose[9]. With information systems many have advantages, one of which has the potential to develop a variety of knowledge [10]. The type of information system that develops is quite a lot, among them (1) support of business operation, (2) support of managerial decision making[11].

Based on the identification of the problem then this needs to be done on the research study titled "Information Systems for Accreditation Assessment Department of The Web (Case study: Informatic Engineering Department)" to help resolve existing problems programmed study, one of them by designing applications to help existing accreditation report preparation courses. 
Implementation of information systems assessment accreditation the accreditation documents the hope this is easier in the manage and presented. The other benefit, users can search information document in accordance with score forms, so that if known to score a low value has form can be corrected or added documents.

\section{Research Methods}

Research methods used in this research use approach:

\subsection{Engineering data collection}

a. Observation, namely data collection techniques by means of direct observation in the field related data needs are necessary, particularly in the associated document accreditation assessment.

b. The study of the literature, looking for materials for the study of theme-related research both from inside (internal resources, books, journals, proceedings) or from an external source (the internet).

c. Interviews, data collection techniques by means of asking the competent parties in the preparation of the assessment instrument/accreditation.

\subsection{System development}

In the journal "Database System", the work of Mihai Liviu Despha (2014) with the title of the publication "Comparative Study on Software Development Methodologies", There are a number of system development methodologies that can be used in software development, i.e. waterfall, prototyping, iterative and incremental, spiral, rapid application development, scrum, cleanroom, adaptive software development[12]. On the research of the selected system development engineering-based prototyping. Prototyping definition is the methodology used to develop program (defining the specifications of the software) according to the needs of users and change instantly[13]. Prototyping methodology in tune with the needs of accredited courses that continue to evolve.

a. Research

Identify all the functions of the program be implemented. The accreditation program in the function needs quite complex so it takes a complementary data (forms) in order to better program presentation

b. Planning

Specify the option platform mobile applications are web-based, desktop, mobile (android). Platforms is an important element of software development as a place to run the software. In real life, the programmer does not always have to choose the platform best for application development. Planning is optional because in principle the programmer has the ability to determine the approach towards applications that are being developed.

c. Design

Software design in fact does the designing of all the needs that have been identified. Design in the software consists of three types: (1) Top-down i.e. break the system into the smallest so easy to grasp, (2) Object-oriented IE uses the concept of object-based 
approach, in which each object has a the relationships between object, and (3) use the diagram to unified model language (UML), which is part of a tool for showing the relationships between classes (in the system) and classes (external entity).

d. Prototype

A prototype is the process of creating a simple model of the software. With prototypes developers and users can be mutually interacting during the making of the program. According to Khrisna, et al model prototype suitable for dynamic environments where requirements often vary considerably. The process starts by collecting all the main functional requirements, then followed the design that lead to the development of prototypes and evaluated by users [13].

e. Feedback

Feedback is used to provide input to change the software. Feedback on the properties used to check and repair the input from the user.

f. Developing

The stages of the application of the system after the system design is approved. This system has been developing position ready.

g. Testing

According to Sukanta Basak \& Hosain a good software process must have to address the following two issues : bug prevention so that fixing bugs at later phases does not increase the cost of development and risk minimization so that unwanted situations do not increase the delivery time[14]. Software testing is a technique aimed at evaluating an attribute or capability of a program or product and determining that it meets its quality. Software testing is also used to test the software for other software quality factors like reliability, usability, integrity, security, capability, efficiency, portability, maintainability, compatibility [15].

h. Setup

The Setup is combining software modules into one unified file ready to use and can be executed by the user.

i. Maintenance

According to Thomas Pigoski in his book entitled,"Software Maintenance", software maintenance sustains the software product throughout its life cycle. Modification requests are logged and tracked, the impact of proposed changes is determined, code is modified, testing is conducted, and a new version of the software product is released. Training is provided to users[16].

\subsection{The Framework Of Thought}

The framework of thought is the concept of a frame narrative of the problem solving that has been identified or deduced. The framework was built with the aim to facilitate the implementation of the program. 


\section{Opportunities:}

a) Added each year to the course pretty much

b) The number of courses that have not been accredited (5,838 collages not yet be Accredited, source: Ministry of Research, technology and higher education, 2018)

c) The existence of a correlation between collage and the competence of graduates, so that the competence of graduates in College enough taken into account must first settled as well as need evaluation.

\section{Weakness:}

a) The difficulty of displaying the scores/rating form

b) Accreditation documents are still scattered (the conventional way on saves), so it is difficult to find information and can even get damaged

c) Creation of reports (accreditation), which takes a long time. Even close to scoring form is due to the supporting attachments of the form unknown
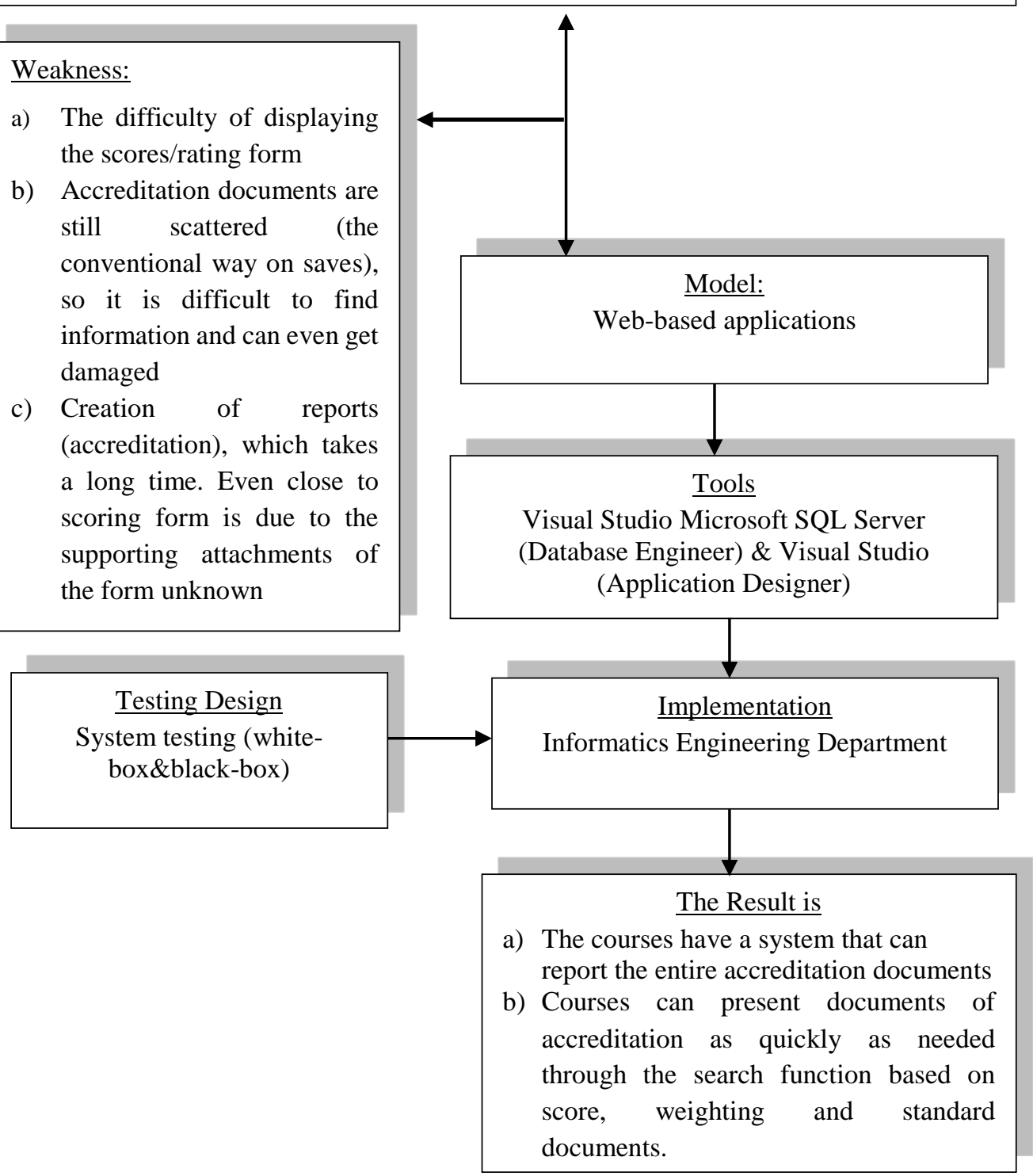

Fig. 1. Research thinking framework. 


\section{Results and Discussion}

\subsection{Analysis of the problem}

Some problems of courses that are often encountered when towards the implementation of accreditation are : (1) the document is difficult to find, because the documents scattered in some places and not in the form of a physical report softcopy, (2) The document is not updated and consistent, so that the required documents have different information on each standard, (3) Scoring some of the documents (which have met the standards but do not meet the standard) are still done by manual process, (4) The relevance of the association documents in each standard are not recorded properly, (5) the difficulty of categorizing assessment in each standard, along with the details of the assessment, (6) accreditation Report Creation is done conventionally takes a long time.

\subsection{Sistem model and system design}

In the article by Terry Bahil \& Rick Botta (2008) published in the journal "Engineering Management" titled "Fundamental Priciples of Good System Design " There are many approaches in designing good software. Approaches is identified it is not absolutely be authority among programmers. Some approaches can be selected one to build the system, such as: use models to design systems, use hierarchical, top-down design, work on high-risk items first, Prioritize, control the level of interacting entities, design the interfaces, produce satisficing designs, do not optimize early, maintain an updated model of the system, develop stable intermediates, use evolutionary development, understand your enterprise, state what, not how, List functional requirements in the use cases, allocate each function to only one component, do not allow undocumented functions, provide observable states, rapid prototyping, develop iteratively and test immediately, create modules, create libraries of reusable objects, use open standard, identify things that are likely to change, write extension points, group data and behavior, use data hiding, write a glossary of relevant terms, envelope requirements, create design margins, design for testability, design for evolvability, build in preparation for buying, create a new design process dan change the behavior of people[17].

In this study researchers use "use model to design systems" to build a system of accreditation. System design in principle is to translate the system into the form of a document based on function or requirements based on their model. Software engineering approach using model designer and has no other purpose for increasing the efficiency and thoroughness. This technique was first developed by Why more's (1993) in his book entitled "Model-base System Engineering”[17].

\subsubsection{The design of a table}

The design of assessment system of accreditation on the research here is to design the database and all the possibilities of the required tables. In the whole database tables have a relationship with one another to produce information systems. This research used a database MS SQL Server version 2017 with the programming languages visual studio 2017 (ASP.Net). In this accreditation assessment system needed some tables to store its. The tables include: 
Table 1. Table of assessment system of accreditation.

\begin{tabular}{|c|c|c|}
\hline No & The Table Name & Description \\
\hline 1 & Dbo. students & $\begin{array}{l}\text { Used to record the data of students which include student number, } \\
\text { name, address, city, department, date of birth, status, phone, email }\end{array}$ \\
\hline 2 & Dbo. courses & $\begin{array}{l}\text { Used to record the data courses, include course name, course code, } \\
\text { credit, semester,curriculum, time, description }\end{array}$ \\
\hline 3 & Dbo. Lecturer & $\begin{array}{l}\text { Used to record the data of lecturer which include lecturer number, } \\
\text { name, city, address, email }\end{array}$ \\
\hline 4 & Dbo. Research & $\begin{array}{l}\text { Used to record the data research which include: lecturer number, title, } \\
\text { year, budget, kind of research, description }\end{array}$ \\
\hline 5 & Dbo. thesis & $\begin{array}{l}\text { Used to accommodate students ' thesis, including: student number, } \\
\text { course code, thesis title, year, status, published }\end{array}$ \\
\hline 6 & Dbo.proposal & $\begin{array}{l}\text { Used to accommodate students ' proposals which include: student } \\
\text { number, course code, thesis title, year }\end{array}$ \\
\hline 7 & $\begin{array}{l}\text { Dbo. Finance } \\
\text { Thesis }\end{array}$ & $\begin{array}{l}\text { Used to house finance thesis, include: student number, date, pay, } \\
\text { description }\end{array}$ \\
\hline 8 & Dbo.document & $\begin{array}{l}\text { Used to hold data of type pdf, jpeg and other documents, including the } \\
\text { code, std, document of name, description }\end{array}$ \\
\hline 9 & Dbo. weights & $\begin{array}{l}\text { Used to provide weighting on the score in accordance with the } \\
\text { standards of the respective }\end{array}$ \\
\hline 10 & Dbo.matrix & The standard used for the calculation of each item (the default number) \\
\hline 11 & Dbo. assessment & Used to give a score on each standard number \\
\hline
\end{tabular}

\subsubsection{The user programme}

In this research the user programs are still single user based, where all data/documents managed by an operator assigned to from program studies. Carmel, Whitaker and George (1993) user are defined as a person who participated in developing the new system [18]. Users can help system developers build document files as reference for the new system, and they can help the system developers make the balance between the technical aspect and the simplification aspect as well[19]. Benefits of user involment in system design : (1) improved quality of the system a rising from more accurate user requirements (2) avoiding costly system features that the user did not want or cannot use (3) improved levels of acceptance of the system (4) greater understanding of the system by the user resulting in more effective use and (5) increased participation in decision-making in the organization[20]. On the implementation phase of the user roles very decisive, because in the process of implementation is this system must be accepted so that the required acceptance test system (also known as acceptences testing). Isaacs \& Olson (1979) says acceptance testing ended when users feel confident that the system can run well and at this point that system must can be operated in full [21]. The user in engagement the system as a whole is very important to the success of development projects, though sometimes the user giving inaccurate information to the system developer [19].

\subsubsection{Program interface design}

The design of the interface of the program part of a which is not integral in building software. The program's interface is needed in order to explain the object-object and a set of operations that can be used to manipulate the object. Processes in detail in the creation of the interface such as: (1) collect information from the user (2) designing the interface (3) developing the interface. 
Here's one example of the design of the interface of the program assessment accreditation of study programs (figure 2).

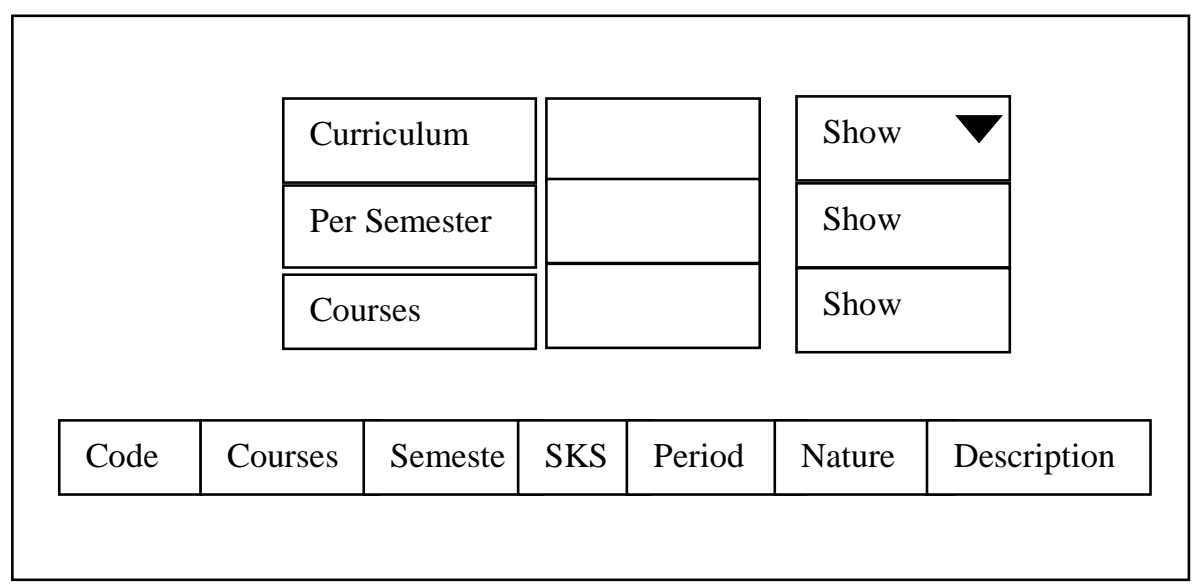

Fig. 2. Data interface design curriculum..

The interface data curriculum in figure 2. Shows detail information display data curriculum. Some properties that could be presented to the user the name of the curriculum that is being actively used, code courses, the name of course, university credit unit (sks) and active period. Data curriculum provides a description of all course that are used in the lecture courses.

\subsection{Implementation of the Programme}

To on the implementation of the program done the application against the draft design of the interface that have been designed before. The implementation describes the actual program can be real in the execution and providing external users see fit. Figure 3 shows one of the results of the implementation of the program in the form of report publication lecturer of Informatics Engineering, published abroad, accredited national and national are not accredited. 


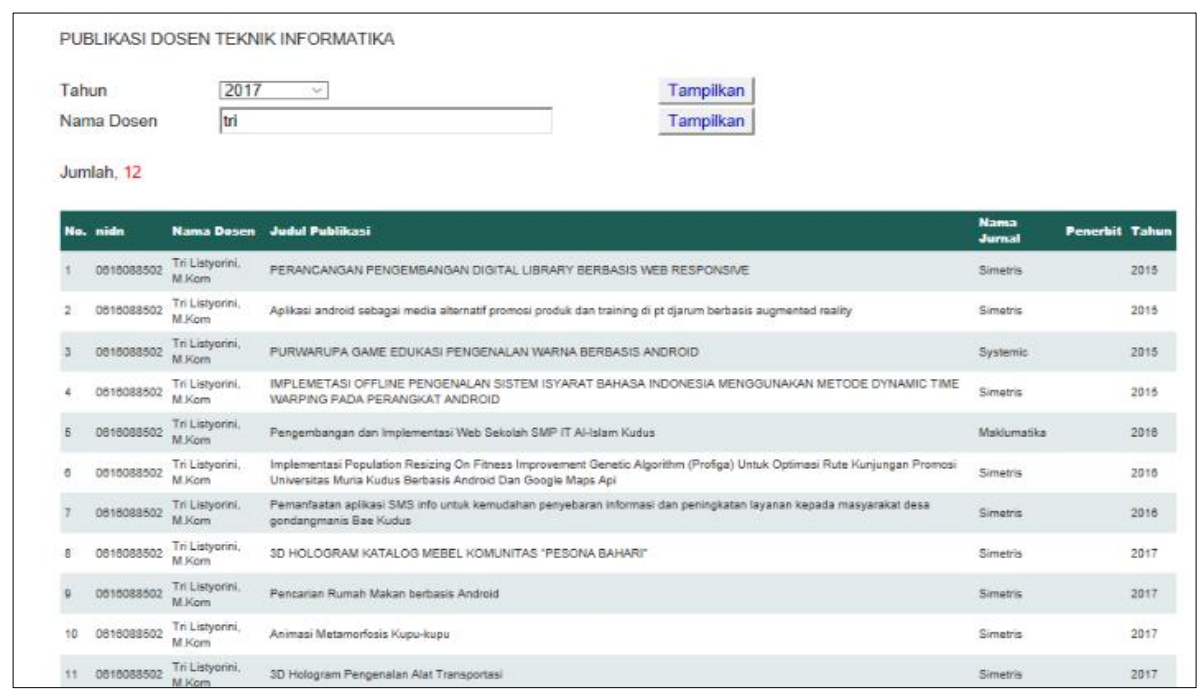

Fig. 3. The result of the publication of a lecturer of informatics engineering.

Data publication of results data for the lecturer research conducted by the lecturer of Informatics Engineering published several journals. From these data it can be known the name of the lecturer, the title of the publication, the journal name and year of publication. In addition to the publication of the data in this study are presented research results and the community services result (figure 4)

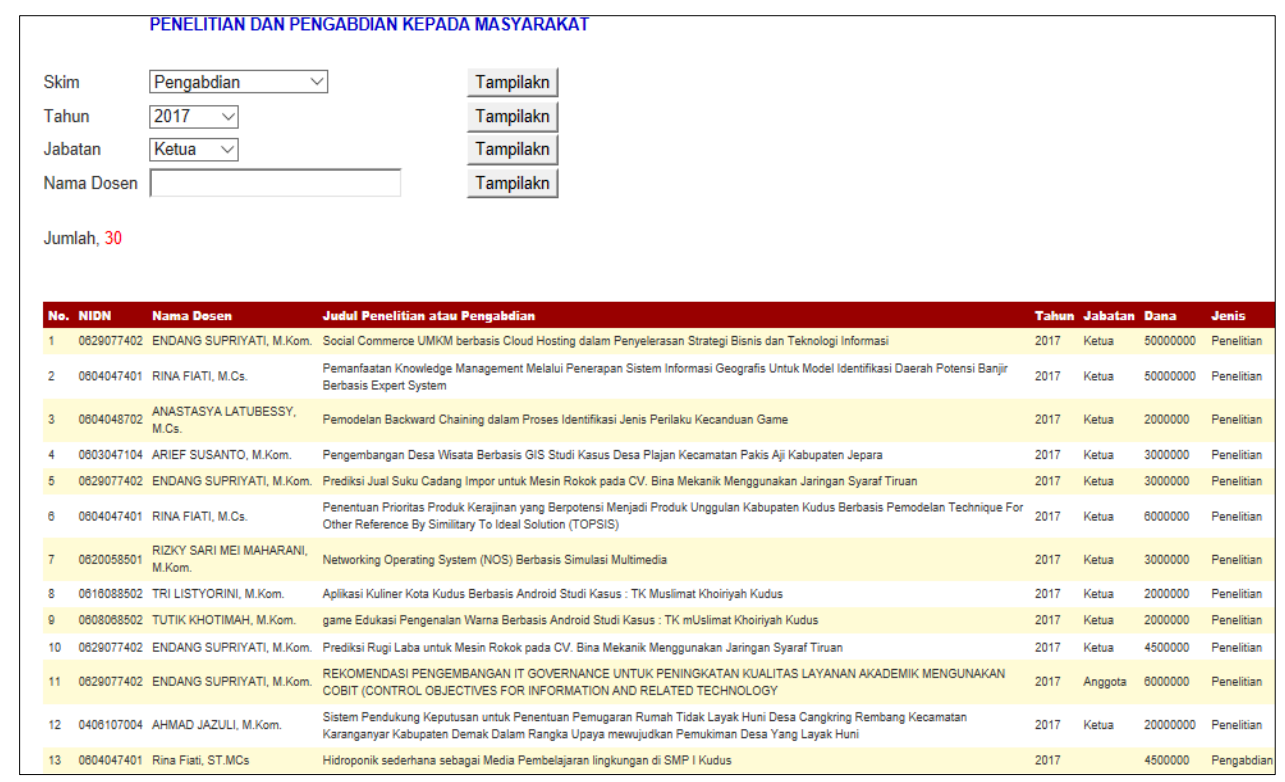

Fig. 4. Results of the study and devotion to society lecturer. 
Research and devotion to the people is one form of tri dharma lecturer required each semester is met. From the research a report may be known to all the lecturers and research include the title of the research, years of research, the budget and the kind of research. Of the form can throughout the research and lecturer over the last, three years and their vulnerable charges used (figure 5).

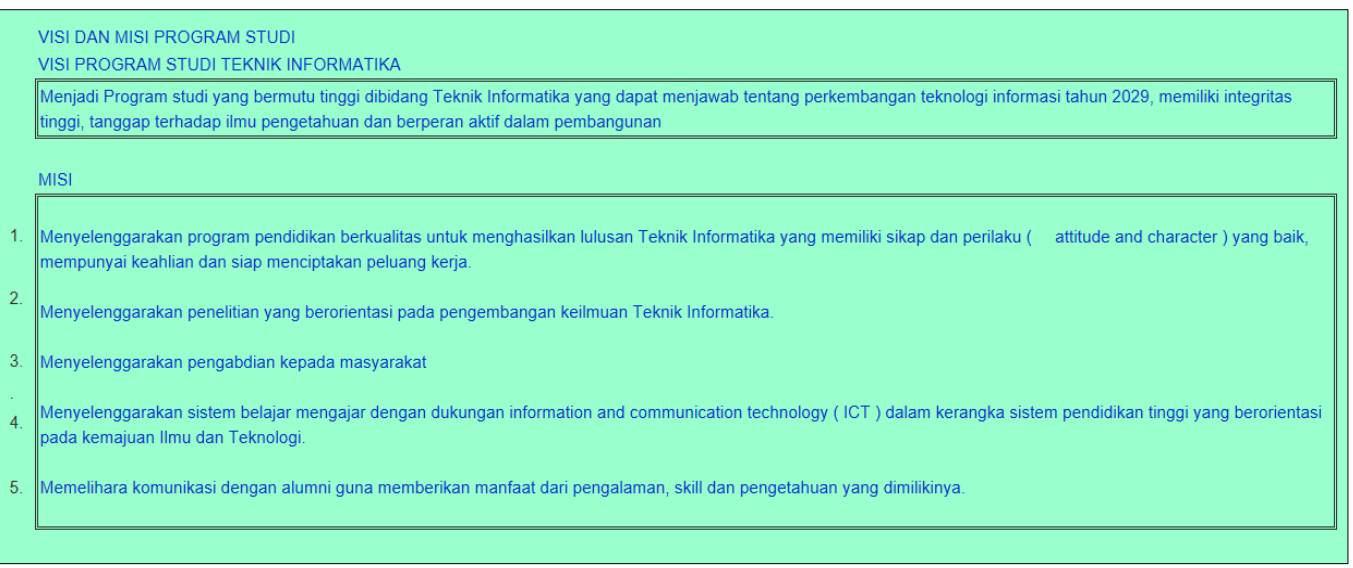

Fig. 5. Document vision mission study program.

Vision and mission study program document is a document that describes the vision and mission of the informatics courses (figure 6). With the document's vision and mission, courses can develop the direction of academic-based research (research and devotion to society).

\begin{tabular}{|c|c|c|c|c|c|c|}
\hline & & & & Mencari Judul Skripsi Mahasiswa & & \\
\hline & K Judul & keputusan| & $\times$ & Tampilkan & & \\
\hline & Angkatan & $2009 \vee$ Tampilkan & & & & \\
\hline Dite & mukan $80 \mathrm{~J}$ & Judul & & & & \\
\hline No. & Nim & Nama Mahasiswa & Judul Skripsi & & Pembimbing Utama & Pembimbing Pembantu \\
\hline 1 & 201151158 & Ratna Dwi Astuti & Sistem Pendukumg & tusan untuk menentukan bakat dan minat olah raga pada siswa & RINA FIATI, M.Cs. & $\begin{array}{l}\text { ANASTASYA LATUBESSY, } \\
\text { M.CS. }\end{array}$ \\
\hline 2 & 201251157 & 7 Hadi Supriyanto & Sistem pendukung & usan diaknogsapenyakit gangguan tiroid menggunakan metode profile & RINA FIATI, M.Cs. & AHMAD JAZULI, M.KOM \\
\hline 3 & 201151177 & 7 Muhammad Irfan Nafis & Sistem pendukung & Usan penentuan balita sehat menggunakan metode WP & RINA FIATI, M.Cs. & $\begin{array}{l}\text { MUKHAMAD NURKAMID, } \\
\text { M.Cs. }\end{array}$ \\
\hline 4 & 201051121 & $\begin{array}{l}\text { Septian Endra Adi } \\
\text { santiko }\end{array}$ & $\begin{array}{l}\text { Sistem pendukung } \\
\text { pengiriman kontiner }\end{array}$ & usan tentang perhitungan bahan kayu pada barang mebel untuk & ARIEF SUSANTO, M.KOM. & TRI LISTYORINI, M.KOM \\
\hline 5 & 201151062 & 2 Yoga Prasetia & Sistem pendukung & usan untuk pemilihan sekolah menengah pertama (SMP) & $\begin{array}{l}\text { MUKHAMAD NURKAMID, } \\
\text { M.Cs. }\end{array}$ & TUTIK KHOTIMAH, М.KOM \\
\hline 6 & 200951065 & Arif Maulana Hidayat & Sistem Pendukung & tusan kelayakan simpan pinjam dengan metode SAW & $\begin{array}{l}\text { MUKHAMAD NURKAMID, } \\
\text { M.Cs. }\end{array}$ & $\begin{array}{l}\text { ANASTASYA LATUBESSY, } \\
\text { M.Cs. }\end{array}$ \\
\hline 7 & 201151209 & 9 Endah Listyaningrum & Sistem pendukung & usan pemberian pinjaman modal pada usaha kecil dan menenga & RINA FIATI, M.Cs. & RATIH NINDYASARI,M.KOM \\
\hline 8 & 201151273 & 3 Royyan Himami & Sistem pendukung & usan penentuan bantuan program kartu indonesia pintar & RINA FIATI, M.Cs. & RATIH NINDYASARI,M.KOM \\
\hline 9 & 201251028 & 8 Dwi Hesti Pebriani & $\begin{array}{l}\text { Sistem Pendukung } \\
\text { dengan metode SA }\end{array}$ & tusan Pendaftaran siswa baru (Study kasus: SMP Negeri 1 Klabu) & $\begin{array}{l}\text { MUKHAMAD NURKAMID, } \\
\text { M.Cs. }\end{array}$ & $\begin{array}{l}\text { RIZKYSARI MEIMAHARANI, } \\
\text { M.KOM }\end{array}$ \\
\hline 10 & 201251002 & 2 Achmad Saifuddin & $\begin{array}{l}\text { Sintem pendukung } \\
n n\end{array}$ & tusan penentuan juara kontes burung berkicau menggunakan metode & RIZKYSARI MEIMAHARANI, & MUHAMMAD MALIK HAKIM, \\
\hline
\end{tabular}

Fig. 6. Student thesis document study program. 
Student thesis document is used to find the final task all students in courses of Engineering Informatics. These thesis documents can be used as the involvement of students in research and community service lecturer (figure 7). These can be of the form also known the name of supervising thesis students.

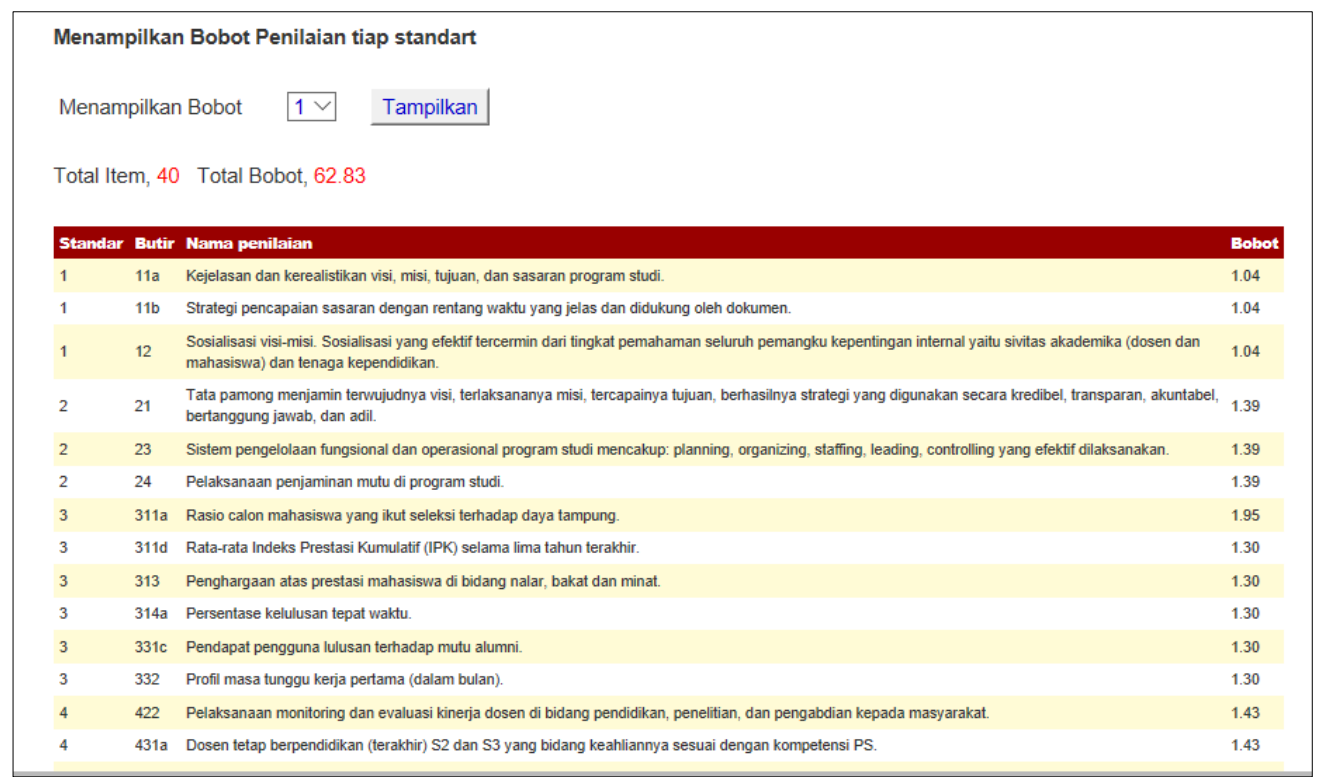

Fig. 7. Weighting of assessment standard accreditation form.

In figure 8 presented a form that can be used to see the weight of the largest and the smallest, so this form it is possible to choose the greatest weights so that the result is maximum. Figure 3.7 is displaying data based on each standard. For example, the standard 1 any grain, grain 2 standard whatever. In addition consists of several rounds in this application can also be seen each value of each grain. 


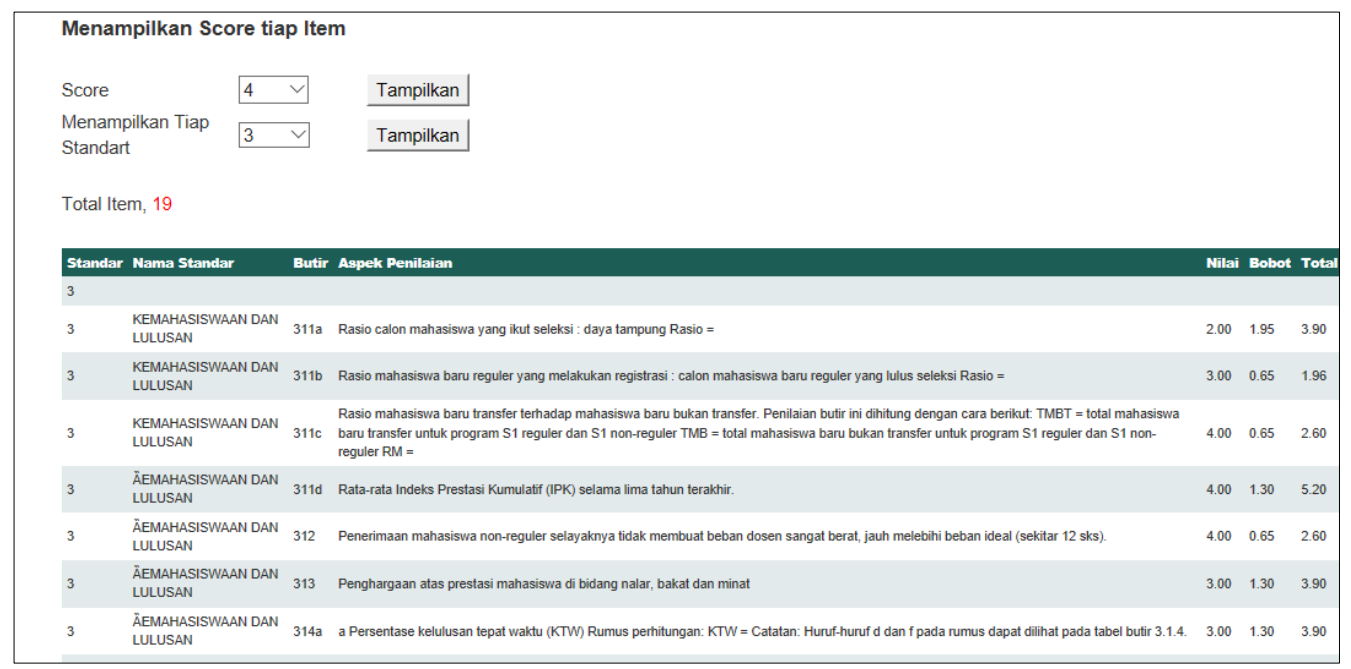

Fig. 8. Showing grains of this aspect of the assessment.

\subsection{Testing The Program}

Testing is an activity to evaluate the quality of software and improving it by removing errors in it. Hence, the goal of testing is systematical detection of different classes of errors in a minimum amount of time and with a minimum amount of effort[22]. The testing program is the final stage of software development is being done in research. The objective of software testing according to Umar Farooq Sheikh \& Quadri in the journal entitled, "Software Testing: Goals, Principles, and Limitations", There are 4: (1) the test in order to verify and validate software (verification and validation), make sure the software must meet conditions set out appropriate product requirements, (2) Testing with a scale of priorities and spaces in scope (priority coverage), testing needs to be set reasonably and prioritizing efforts. Generally every feature should be tested with at least one case of valid input, (3) testing is in order as the stabilisation, testing must balance between the written requirements, technical implementation in field results and expectations of users, (4) Testing as documentation of the success and failure of the program, testing should be clear what is being tested, and how to do done. Documentation testing are used as a means to eliminate repetitive testing effort that has perpetrated[23].

On testing the prototype system for the accreditation of the testing approach is used white box testing dan black box testing. Testing white-box testing the test is based on checking to detail design, use of control structures in program design prosecedural to split testing to test in some cases (sub-programs). White box testing has several advantages that can check a variety of conditions: (1) logic errors; (2) mismatch the assumption; (3) typographical errors. Blackboxtesting the test is done after testing white-box, based on observation results of execution through test data and examine the functional and the output of the software. Testing black-box programmers trying to identify some errors on the software, related: (1) the function of which is not correct or missing, (2) fault structure database, (3) initialization or termination, and (4) errors interface. 


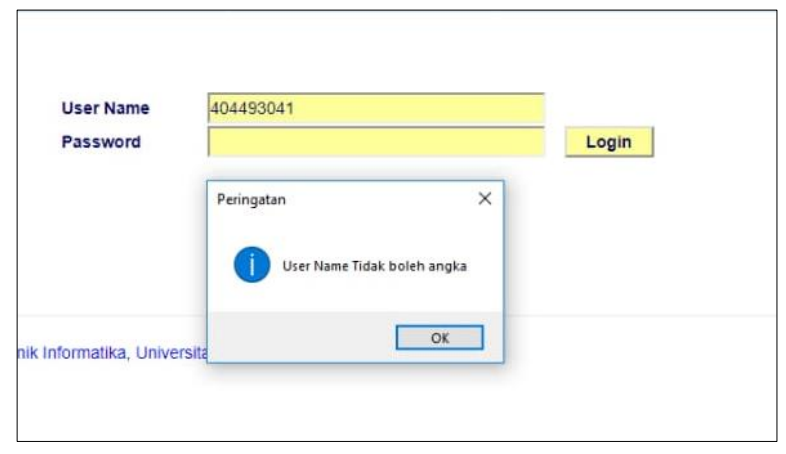

Fig. 9. One of the testing white-box for memfalidasi users.

\section{Conclusion}

This research can take some conclusions:

a. The courses have a system that can build the entire document accrediting the required course of study. The document includes vision and mission for goal of the course, lecturer, academic documents, data research financing devotion, facilities and infrastructure of data, data research and dedication professors, active students, the students leave, the amount of fixed data lecturer curriculum courses and graduate data.

b. The system of accreditation of study programs can provide the assessment objectively, related documents below standard so that courses can enhance existing standards with a complete the required documents.

c. The system of accreditation of study programs can present documents quickly as needed through the search function based on score, weighting and standard documents.

\section{References}

[1] B. PT, Buku V Pedoman Penilaian Instrumen Akreditasi Program Studi Sarjana. Jakarta BAN PT, 2009.

[2] D. Setiawan, "5000 Program Studi Belum Terakreditas," Pikiran Rakyat, 2017.

[3] M. S. Widodo, "Kemenristekdikti: 5.838 Prodi Perguruan Tinggi Belum Terakreditasi," Gatra.com, 2018.

[4] H. M. Siti Nurmiati, "Sistem Informasi Kegiatan Akademik Untuk Akreditasi Program Studi Berbasis Web Studi Kasus Program Studi Manajemen Sumberdaya Perairan IPB,” J. Sist. Inf., vol. 5, no. 5, 2016.

[5] P. Kumar, "Information Technology: Roles, Advantages and Disadvantages," Int. J. Adv. Res. Comput. Sci. Softw. Eng., vol. 4, no. 6, 2014.

[6] Davis, Information Systems Conceptual Foundations: Looking Backward and Forward. Springer, 2000.

[7] M. N. Kalle Lyytinen, "Punctuated Equilibrium, Process Models and Information System Development and Change: Towards a Socio-Technical Process Analysis," Work. Pap. Inf. Enviroments, Syst. Organ., vol. 6, no. 1, pp. 1-48, 2008.

[8] P. M. Mark Huber, Craig Piercy, Information System:Creating Business Value. John Wiley \& Sons, Hoboken, NJ, 2007.

[9] R. M. Stair, Principles of Information Systems: A Managerial Approach. Boyd and Fraser (division 
of Southwestern Publishing Co.), 5101 Madison Road, Cincinnati, 1992.

[10] S. Alter, "Defining Information Systems as Work Systems: Implications for the IS Field," Bus. Anal. Inf. Syst. Sch. Manag. Univ. San Fr., 2008.

[11] N. A. Yaser Hasan Al-Mamary, Alina Shamsuddin, "The Role of Different Types of Information Systems In Business Organizations : A Review," Int. J. Res., vol. 1, no. 7, 2014.

[12] M. L. Despha, "Comparative Study on Software Development Methodologies," in Database Systems Journal, Faculty of Cybernetics, Statistics and Economic Informatics from the Bucharest Academy of Economic, vol. 5, no. 3, 2014.

[13] K. R. K. R. S.Thulasee Krishna, S.Sreekanth, K.Peruma, "Explore 10 Different Types of Software Development Process Models," Int. J. Comput. Sci. Inf. Technol., vol. 3, no. 4, 2012.

[14] M. S. H. Sukanta Basak, "Software Testing Process Model from Requirement Analysis to Maintenance," Int. J. Comput. Appl. ECE North South Univ., vol. 107, no. 11, 2014.

[15] P. M. C. Abhijit A. Sawant, Pranit H. Bari, "Software Testing Techniques and Strategies," Int. J. Eng. Res. Appl. (IJERA),Department Comput. Technol. VJTI, Univ. Mumbai, India, vol. 2, no. 3, 2012.

[16] T. M. Pigoski, Software Maintenance. Technical Software Services (Techsoft), Inc. 31 West Garden Street, Suite 100 Pensacola, Florida 32501 USA, 2001.

[17] R. B. A Terry Bahil PE, "Fundamental Principles of Good System Design," in Engineering Management Journal, vol. 20, no. 4, 2008.

[18] J. F. G. Charmel, Erran, Randa D Whitaker, "PD and Joint Application Design: A Transatlantic Comparison," Assoc. Comput. Mach. Commun. ACM, vol. 36, no. 6, 1993.

[19] Z. Sun, "User Involvement in System Development Process," Proc. 2nd Int. Conf. Comput. Sci. Electron. Eng. (ICCSEE 2013) ,Department Inf. Sci. Technol. Tianjin Univ. Financ. Econ. Tianjin, China, 2013.

[20] L. Damodaran, "User Involvement In the Systems Design process A Practical Guide for Users," Behav. Inf. Technol., vol. 15, no. 6, pp. 363-377, 1996.

[21] O. R. E. Isaacs, G U., "Successful System are Designed by Users," Infosystems, p. 48, 1979.

[22] S. S. Ghuman, "Software Testing Techniques," Int. J. Comput. Sci. Mob. Comput. Khalsa Coll. Domeli Punjab, India, vol. 3, no. 10, 2014.

[23] S. U. F. Quadri, S.M.K, "Software Testing - Goals,, Principles, and Limitations," Int. J. Comput. Appl. Comput. Sci. Univ. Kashmir, vol. 6, no. 9, 2010. 